\title{
Venture capital and microfinance: an instrumental approach ${ }^{*}$
}

Romar Correa ${ }^{\dagger}$

Amelia Correa $^{\ddagger}$

\begin{abstract}
Following Adolph Lowe, we divide the economy into two sectors, equipment-goods industries and consumer-goods industries, operating over two periods. A structural relationship between the outputs in the two periods is given by a set of inequalities. One possible outcome is a state of less-than-full utilization of available resources. The economy consists of firms and households. Firms are technology entrepreneurs possessing blueprints for the transformation of the existing inefficient level of output to a full employment level, but no wealth. A subset of households, venture capitalists, is available in each of the three sectors. They finance the technologies in exchange for a share of the profits. We show that a stationary equilibrium exists only in the case when financial contracts are written in the second sector.
\end{abstract}

Keywords: structural analysis, force analysis

JEL Classification: G24, 041

\footnotetext{
${ }^{*}$ We are grateful for the variegated attention given to an initial draft by a set of anonymous referees. The usual caveats apply.

† Department of Economics, University of Mumbai, email address: romarcorrea10@gmail.com

‡ Department of Economics, St Andrew's College, University of Mumbai, email address: ameliacor@gmail.com
} 


\section{Introduction}

Microfinance is under siege as scholars and other appraisers look within and discover huge inefficiencies. The vaunted model of peer pressure has been found to conceal arm twisting and more. Not even Muhammad Yunus and the Grameen Bank have been spared. One reason is that the unique status of the project has blurred over time and schemes have begun to cleave to established banking systems and practices. In India recently, the market for bank licenses has opened and the first to be granted permission to become a bank is a microfinance institution, Bandhan. Immediately, the promoters set about flattening the profile of the institution so as to meet with commercial banking yardsticks. At the same time, top officials in the commercial banking sector wondered at the decision to add another member to their full camp to the detriment of activities, which were in need of support. In so doing, microfinance becomes partner to the dance of international finance (Wagner and Winkler, 2013). During the golden epoch of financial capitalism, which concluded in 2008, agents on the ground fell under the sway of global optimism and were less rigorous in the application of conservative appraisal techniques. Microfinance enterprises that tapped domestic and international capital markets more aggressively in the pre-crisis period recorded large declines in credit growth in the crisis period. However, enterprises with careful credit technologies and a high degree of flexibility among microenterprises about employing assets productively were relatively unscathed. The financial accelerator is mirrored in local arrangements.

Our preliminary interest arises here. Microfinance has come under the purview of monetary policy and can, therefore, be subjected to the discipline of macroeconomic reasoning. In this regard, given the gargantuan task of addressing poverty, the belief has gained ground that, in retrospect, microfinance could never have been more than a palliative to start with. Secondly, an emerging consensus is that while financing schemes for the poor are laudable in principle the incentives and constraints under which the concerned parties will operate cannot be ignored. Our primary impulse, therefore, is to give a scholarly treatment to the connection between so-called 'angel funding' and microfinance.

Academic work on the subject is thin absent a few exercises in applied microeconomics. Thus, recent work compares and contrasts the model of peer pressure with the informational problems that intrude in the bilateral bargains between individual borrowers and lenders. Fully-specified general equilibrium models with microfinance are hard to find. On the other hand, social economics offers a menu of options. Here, the concept of social control is central. Since the expression might have connotations the opposite of those intended, it has to be stated that social control expands the opportunity set of the agent beyond what exists in her autonomous optimization exercises. The task is to articulate mechanisms that regulate the behavior of actors in the direction of compliance of social rules. An understanding of the intelligent guidance of the functioning of the economy is sought. The loci of choice are indissolubly monetary and financial. Both are part of the dialectical exchange between private decisions and public rules. People enter into contractual relations supported by rules of debt. These debts circulate through the economy under the overarching constraint of fulfillment at the end of payment cycles. Also, our orientation is not different from the "varieties of capitalism" line of thinking in that we cut through the Market versus Plan debate old and new (Sawyer, 2013). In so-called "coordinated market economies" firms develop non- 
market relations to construct their core competencies. There is widespread relational contracting, a greater reliance on collaborative rather than competitive relationships. Efficiency and optimality are the goals of a cooperative community of people consensually seeking the best way to organize their interactions. Institutional variety is paramount here as local economies specialize in particular products and processes.

The familiar account of the trials and tribulations of an agent are alleged to have their origin in Adam Smith but, in Smith, the influence of institutions on individuals is vital (Menudo, 2011). The butcher, the baker, the candlestick maker are believed to be endowed with sympathy which is the socialization required for the formation of exchange value. Our approach could also be described as a "social institutionalist" approach to the topic (Lecouteux, 2013). Accordingly, as even in the economics of Léon Walras, the starting point is mechanisms that operate at the level of society and, thereupon, the behavior of individuals that illuminates those social forces. In such a line of thinking that extends through Alfred Marshall right up to Thomas Schelling, the concern is with feedback loops that, originating with observed social outcomes, seek to provide accounts of individual behavior that explicitly generate institutions and simultaneously are created by them for the solution of specific problems.

While heterodox economists have welcomed the institution, microfinance is rarely found in their models. We enter the space of contention between micro-sensitive and purely structural non neoclassical economics. For instance, we pick up the gauntlet thrown by Lee and Tae-Hee (2010). ${ }^{1}$ The social provisioning process is a continuous series of production-based activities that provide necessaries to individuals and families. The production process, in turn, is an input-output matrix with labor power as input. However, the level and composition of the social product cannot be taken as given. Social agency is embedded in the system to give it a specific character and purpose. Money and finance enter in the relationship between wages and profits. Profits in the national accounts defined by political economists are not business profits but entrepreneurial profits, the surplus at the discretion of business that does not lower their stock of wealth. In a structural description, the task of the analyst is to trace the impact of a change in the price of a good or service in one sector on other sectors.

The join between micro and macro is institutionalist economics but the subject, we have on respected appraisal, is not just about minimizing transaction costs (Langlois, 2013). Alternative institutional configurations minimize the sum of transactions and production costs. Indeed, there might often be tradeoffs between the two. In the end, changes in relative prices and factor abundance play no small role in engendering institutional variety. Our contribution is the introduction of financial arrangements into these real accounts. The plan is to construct a macro-frame which is the elaboration of conditions under which financial innovation can occur (Engelen et al., 2010).

One facilitator has been the continuing process of State restructuring following the crisis of Keynesianism in the late 1960s/early 1970s. Restrictions on cross-border financial transactions were dismantled leaving financial agents with adequate liquidity to innovate with. Entrepreneurs must have an eye for the new opportunity, upscale quickly and capture higher

${ }^{1}$ See also Lee (2011) 
margins before commodification sets in in a product cycle of four to seven years typically. In the absence of a general system of property rights in financial innovation, novelty is critical because offering the same contracts every year brings in imitators and reduces first-mover advantages. The flush of securitization might have already faded, for instance, independent of the financial crisis it underpinned. Secondly, they must organize a division of labor or ownership which channels cash to well-positioned users. The term bricolage is used in social studies of finance (see, for instance, MacKenzie and Pardo-Guerra, 2014). Early adopters of new financial practices are able to discern idiosyncratic features in the data that were ignored or devalued. With bricolage, extant practices and the environment disclose new ways to apply the technology to the material. These practices are situationally specific and exploit local context. Financial innovation is contingent because bricolage, in each new conjuncture, constructs a world that escapes previous schema.

We use the model of the social economist Adolph Lowe to formalize our argument. Recently, his work has been cited as seminal in the modeling of interdependent subsystems that must be married to Post Keynesian microeconomics and finance to make the leap forward in realist macro analysis (Seppecher, Salle and Lavoie, 2017). But before we do so, we explicate the aspects of the connection between venture capital and microfinance that are germane to our case.

\section{Venture Capital and Microfinance}

The problem of funding economic activity goes back to Keynes when he explicated that in modern systems savers and investors were not necessarily identical. The former class accumulated reserves by not consuming all their income while the latter consisted of people with ideas and projects and with resource constraints. The problem of the capitalist system was to coordinate the two sets of decisions. Unemployment was the outcome of the aggregate mismatch between the two sets of plans. Contemporary capitalism can be compared with the early Roman empire in the menu of options it avails of to solve the problem of finance (Temin, 2004). Informal external sources of capital were used in primitive financial societies and are also utilized today as integral parts of sophisticated financial systems. They were often connected with equity capital in the form of informed investors.

The forerunners of modern venture capitalists (VCs) were some early joint-stock companies that acted as intermediaries providing equity capital on an individual basis. They used their resources to fund several activities or groups. Savers purchased shares of these companies to become party to the average fortunes of these ventures. They were not making a bank deposit with its risk-free, albeit low, return. Joint-stock companies sent out expeditions and invested from the pool of resources garnered by selling shares. In modern times the contours of alternative financing modes seems to be sharper (Schäfer et al., 2004). Venture capital, rather than bank financing, is associated with high-risk projects. In the theoretical models, the VC possesses high-order screening, monitoring and managerial skills. This expertise is of greater value for high-risk enterprise. VCs usually write equity-type contracts. They regard their raison d'etre as selectors of high-risk, high-return schemes from which they benefit by improving their prospects during the duration of the investment. Other characteristics are as follows: risky enterprises with a low cash flow tend to receive equity financing. Given the costly screening and coaching inputs, large deal sizes will be preferred in 
equity financing. The bank versus VC literature suggests an equilibrium where high-risk projects are equity financed and entrepreneurs with safe projects apply for loan financing. A lower success probability and a higher cash flow work in favor of informed VC financing whereas higher collateral requirements and lower upfront investments underlie debt covenants.

The financial systems paradigm in microfinance is consistent with this agenda (Donaghue, 2004). According to this view, microfinance providers should be resolved to cover their costs since anything less would undermine their ability to achieve the scale necessary to make any inroad into the unfulfilled demands of their clients. Their outreach is to be based on the offering of tailor-made products rather than eligibility rules or other measures denying access. Time should be spent on unearthing services that groups are willing and able to pay for rather than measuring the impact of their services on clients. Proponents of this perspective regard the reduction of poverty as a by-product of the numerous ways in which access to financial services helps poor households. The belief is that by reaching massive scale microfinance providers are likely to reach more of the very poor than many smaller agencies devoting their resources to directly reaching them.

We believe that the tension between the systems approach and what might be called poverty-focused microfinance which lays stress on targeting services can be resolved. Another difference of emphasis concerns the so-called 'promotional' role of microfinancial institutions that ground the creation and growth of microenterprises and the 'protective' role played by these institutions as they facilitate consumption smoothing. A key problem with microfinance is sustainability, that is the ability to withstand massive stochastic shocks (Hollis and Sweetman, 2004). There might be a tradeoff between lending to the very poor and sustainability. The ability to attract deposits is often taken to be an index of financial viability. However, while depositor funding may leverage donor funding to attain a large scale of operations, sustainability might be a casualty. Deposits can be withdrawn without notice in times of crisis. A central problem of microfinance remains sustainability without the continuous infusion of external subsidies. The conclusion is that sustainable financial institutions by this criterion tend to have a low dependence on deposits.

The natural language of financial contracts, agency and contract theory, will be used carefully and critically in dealing with our theme. Banks and clients are members of separated domains to be connected by the economics of asymmetric information. Indeed, the rare case of bilateral private information might intrude here in that the poor have no information about the entities with which they might do business. The only potential connect is resources; one is rich, the other poor. At the same time, there are individuals and groups in the sector that are naturally privy to inside information about the characteristics of the putative poor clients. Indeed, the vilified moneylender is a member of the set. He/she, to recall, is a monopolist. Monopoly pricing is not inefficient in the absence of the inducement to enter and exit. In addition, in this illustration the problem of repeated interaction being truncated by "cheating" or "not truth telling" is solved by deeply-rooted cultural carrots and sticks. Moneylenders are in possession of special enforcement mechanisms but not of the scale of finance required to make a dent in the problem of poverty alleviation. The consensus is that future arrangements must be new institutions that meld the best of both these characteristics rather than serial 
arrangements between independent entities (Aghion and Morduch, 2005). Indeed, the reason for the recent revert to banks in India referred to was precisely the downturn in the fortunes of established microfinance institutions. For instance, the new mechanism must combine the business savviness of the bank manager with a finite horizon and the information bank represented by local functionaries.

VCs that finance and advise start-up enterprises can be regarded as an important adjunct to this case for microfinance (Keuschnigg, 2004). The argument is that a sophisticated venture capital industry makes young firms grow faster, increases value and creates more jobs. A special trait of VCs is that they are oriented towards exit (Mayer, 2004). Thus, the infinite dependence on infusion of inputs like cash is obviated from the outset. An econometrically exacting and comprehensive study of Australia distinguishes between the effects of different VC activities like finance, administration, marketing and management on fund-raising (Cumming et al., 2005). The focus on value addition is important as these distinguish venture capital from other sources of funds. The conclusion is that capital commitments are greater to venture capital funds that provide more financial and management assistance to entrepreneurial firms than administrative and marketing inputs.

Ashford (2013-14) offers a similar binary model. Capital investment, in his framework, has a seven-year recovery period. Capital, in the first place, is employed in the production of goods and services and the distribution of income. Secondly, it promotes the fuller employment of labor and resources over the short as well as the long run. There is no taxation nor government expenditure in his proposal. Recent evidence endorses these expectations (Popov and Roosenboom, 2013). Controlling for country and industry characteristics, VC capital is found to be beneficial in introducing new ideas to the marketplace in the form of new companies. Concerning aggregative effects, VC investment is seen to create value through fostering entrepreneurial activity in the economy. Recently, Albert O. Hirschman's famous distinction has been employed to give credence to voice and loyalty in VC operations instead of exit in the dynamics of competitive economies (Klinger-Vidra, 2016). Freedom of entry and exit is one of the axioms of the theory of the perfectly competitive economy. Venture capital, on the other hand, is loyal and sticks. Providers do not severe relationships if the recipients do not buckle to the lure of short-term gains. For the purpose, they take block-holder positions that protect startups from the pressures of public equity markets. They exercise voice in defending their investments. To that end, they develop an extensive web of coverage to monitor their wards' activities directly. The non-pecuniary returns to their intervention are considerable. Microfinance institutions would have access to cutting edge technology and willy-nilly contribute to the aggregate development of the economy.

The task of development is to transform petty producers into micro-entrepreneurs (Sachs, 2004). The former are involved in small-scale market activities outside the pale of modern enterprise. Their absorption into the mainstream capitalist market will be facilitated by the encouragement of what Sachs calls "collective entrepreneurship" as a means of strengthening their individual initiatives. Organizational innovation can include micro-credit schemes as well as collaborations in the area of technology, design and marketing. The framework should absorb, in addition to Smithian allocative efficiency, innovative or Schumpeterian efficiency and Keynesian efficiency, which consists of full employment of all the 
means of production. Offering a synthetic model will not be easy and a tension between the neo-Schumpeterian and Post Keynesian agendas can be recorded here in the context of our attempts at a resolution (Evangelista, 2015). Allegedly, the former comprises of a turn towards micro explanation and a "positivistic" account of the production process. Furthermore, the claim is that, in contrast to the Post Keynesian, the neo-Schumpeterian orientation is "supplyside". Our answer is that input-output systems are neither "supply-side" nor "demandconstrained" per se. It is true, and we will demonstrate as such, that our model does provide a precise rationale for the destination of finance. We prefer to think of the prescription as "normative" flowing from a "positive" analysis. As suggested, the model that embraces it all is the structural framework of Adolph Lowe to which we now turn.

\section{Structural Analysis}

The classical procedure follows from system principles in that macroeconomic processes are strictly interdependent. They are connected by a series of positive and negative feedbacks that permit the system to grow. Indeed, Brazilian political economy outside the universities played no small role in generating and disseminating applied interdependent systems analysis in the 1920s and the 1930s (Fernández and Suprinyak, 2016). The universities agenda is open and vibrant and has subsequently adopted the best of microeconomic theory to the ends of structural reasoning. Lowe $(1976$, p. 11) recommends prescriptive rather than positive analysis wherein the appropriate means for attaining stipulated goals are laid out. This procedure is called instrumental analysis. Relatedly, structural analysis is concerned with the pattern in which the inputs and outputs, employment and income, saving and investment and so on must be arranged if the economy is to move along a desired path from the initial state to the terminal state. In contrast, and the focus of the next section, is motor or force analysis which elucidates the individual choices that underlie the motion of the system along the optimal trajectory. Thus, continuous, full and efficient utilization of available resources would be a goal in stationary equilibrium. "Real capital" is the key to the analysis of growth in an industrial economy (Lowe, 1976, p. 5,8,10,12,17).

New structural economics offers the following nuances (Lin, 2013). The intermediate project is to develop capital-intensive industries, while the immediate goal is to accumulate capital rapidly. In contrast with the old structural economics, finance is not relegated to the background. However, the financial mechanisms of developing countries need not mimic the institutions of their developed neighbors. Banks and stock markets evolved in the USA and other countries to meet the demands of industry in their specific contexts. For instance, technological innovation and industrial upgradation in the developed world is an expensive business and depends on risky indigenous R\&D. In contrast, developing countries are capital poor. The hypothetico-deductive method is inverted and the terminal state is specified. Not that the articulation of goals is a problem that can be solved simply (Goodwin, 2014). Standard theory provides no hints, only implicit goals. Transition to a post-growth economy requires constraints on production. Thus, Non-Basics and financial production is tantamount to labor that does not create value. The issue, then, is to write down rigorous constraints into short-run optimization problems. The unknowns of the social problem are the behavioral and motivational patterns that set the system on an optimum path as well as public inducements to elicit the appropriate motivations. 
A schema of industrial production is given by dividing the set of finished goods into either consumer goods or equipment goods. Equipment is identified with fixed capital and working capital is called intermediate goods. The equipment goods sector, furthermore, is subdivided into a sector producing equipment to be used in the production of consumer goods and the machine tools sector in which machines are produced by machines. The order of production is divided vertically into the two basic sectors: equipment-goods industries, Sector I and consumer-goods industries, Sector II. The former is divided further into Sector la, producing the equipment used in both Subsectors $\mathrm{la}$ and $\mathrm{Ib}$ and Sector $\mathrm{Ib}$, which supplies Sector II only. In keeping with familiar modern terminology, we denote the outputs of the three sectors as $y^{a}, y^{b}$, and $y$. The inputs flows into the three sectors will be denoted by $n^{a}, n^{b}$, and $n^{y}$ in the case of labor and $f$ as wear and tear of equipment. We can now write the necessary relationships between the outputs of Period I and the inputs in the next period as follows:

$$
\begin{aligned}
& y_{t}^{a} \geq f_{t+1}^{a}+f_{t+1}^{b} \\
& y_{t}^{b} \geq f_{t+1}^{y} \\
& y_{t} \geq n_{t+1}^{a}+n_{t+1}^{b}+n_{t+1}^{y}
\end{aligned}
$$

By transforming these inequalities into equalities, we introduce a goal into the scheme of reproduction, that the available stock of labor and equipment be fully utilized. The schema provides both intertemporal as well as intersectoral relations between inputs and outputs. We can translate the physical quantities into value or price-sum entities by treating the inputs of equipment goods within each sector as homogenous and regarding the labor inputs as homogenous (Lowe, 1976, p. 25,26,31,39). The unit price of the consumer good is stipulated as numéraire. By also equating the value of the consumer-goods output with the aggregate quantity of the output $y$, we obtain the unit price of unity for the consumer good. On this basis, we can determine the unit price of labor $w$ as the ratio of the price-sum of the consumer goods to total labor input. The respective claims of the three sectors on the output of consumer goods can be calculated. $w . n^{y}$ is consumed in Sector II leaving a transfer of $y-w \cdot n^{y}$ to Sectors la and $\mathrm{lb}$ in order to replenish the consumer goods presently absorbed. The transfer takes place in two steps: the aggregate is transferred to Sector $\mathrm{lb}$ to be matched by a reverse flow of the total output of secondary equipment $y^{b}$ to replace the worn-out equipment in Sector II. The price of secondary equipment goods in terms of the price of consumer goods, $p^{b}$, thus turns out to be $y-w \cdot n^{y} / y^{b}$. In like manner, Sector lb can only retain the consumer goods equal to the value of its own labor input. The difference, $w \cdot n^{a}$, is 'exported' to Sector la in order to effect the exchange of the surplus of primary equipment left there, that is, $y^{a}-f^{a}$. Once more the exchange ratio $w \cdot n^{a} / y^{a}-f^{a}$ yields the price of primary equipment goods in terms of consumer goods, $p^{a}$. In value terms, for an equilibrium we have

$$
\begin{aligned}
& p_{t}^{a} \cdot y_{t}^{a} \geq p_{t+1}^{a} \cdot f_{t+1}^{a}+w \cdot n_{t+1}^{a} \\
& p_{t}^{b} \cdot y_{t}^{b} \geq p_{t+1}^{a} \cdot f_{t+1}^{b}+w \cdot n_{t+1}^{b} \\
& p_{t} \cdot y_{t} \geq p_{t+1}^{b} \cdot f_{t+1}^{y}+w \cdot n_{t+1}^{y}
\end{aligned}
$$


In a manner analogous to the physical equilibrium conditions, we obtain the intersectoral and intertemporal requirements for an equilibrium in price-sum space. The following two equations might be highlighted

$$
\begin{aligned}
& p_{t+1}^{b} \cdot f_{t+1}^{y}=p_{t}^{b} \cdot y_{t}^{b} \\
& p_{t+1}^{a} \cdot f_{t+1}^{b}=w \cdot n_{t+1}^{a}
\end{aligned}
$$

In a stationary equilibrium, $p_{t}^{i}=p_{t+1}^{i}=p^{i}, i=a, b$.

Lowe's schemata is intended to elucidate the process of production as a set of interdependent flows that are related to the system's stocks (Lowe 1976, p 33). There are vertical and horizontal and circular flows necessary to keep the system in operation. The schemata is innocent of monetary and financial arrangements. It is only fitting, then, that the introduction of venture capital into the classical flow in the history of thought can be traced to the ruminations of Joseph Schumpeter. Venture capital can rupture the evenly rotating economy in virtuous or vicious ways. Schumpeter borrowed the notion of 'promoter's profit' from Hilferding (Penender and Resch, 2014). It was the capitalized gain from funding, expanding, or restructuring a business and realized by selling new shares. In modern terms this is private equity and with early-stage investments, venture capital. The category of income was sui generis. It was different from loans which earn interest and from trading in equity on the stock exchanges. The implication of the latter is that arbitrage would move the yields on shares to equality with the riskless money rate of interest.

The closed systems property of equilibrium states is at variance with the open systems precept of historically-contingent decision-making. However, according to some fresh appraisals of the classical research strategy, the behavior and negotiations of buyers and sellers as they counterpoise the necessity to be competitive with the imperative of forging long-term links would be a fruitful adjunct to the neo-Ricardian and Post Keynesian research programmes (Downward, 2004). The importance of the price system in disequilibrium cannot be overstated for providing the basis for "force analysis" to operate. In social economics, while individuals are price takers as in neoclassical economics, prices are not the outcome of preferences but reflect the composition of commodities in the concrete material settings of exchange (Beckert, 2011). In particular, the incorporation of venture capital in a macro framework calls for hard structural theory (Gimmon and Levie, 2009). If a meso-level analysis was at stake, the balance would be tilted in favor of the calculus of individual choice.

\section{Force Analysis}

Force analysis is the search for behavioral and motivational patterns that are suitable to the achievement of stipulated macro goals (Lowe, 1976, p 62). The first problem is the discovery of the "behavior patterns" on the part of producing and consuming units that are required to assure the maintenance of structural equilibrium conditions once they have been realized. Thereafter, the "motivational patterns" that sustain the behavioral patterns have to be illuminated.

Motivated behavior in a stationary process pertains to the control of the physical or the value process elaborated upon earlier. This implies coordinated action on the part of decision-making units constituting the system. Such coordinated action is possible only under a system of communication, threats and sanctions. To recap, phenomena emerge from the dynamics of the situation, not from preferences. Thus, primitives like social preferences are rejected (Schlicht, 2013). For instance, notions like "inequality aversion" are not supported in 
the laboratory. It is not obvious that collective behavior will emerge. In some experiments, group polarization is evidenced by escalating brutality. We confine ourselves to working class solidarity generated by the production process. The tendency of workers to adjust to working practices of the group actually renders economic incentives more powerful for the group as a whole. Working class behavior generates a "social multiplier" sequence that strengthens the effectiveness of economic incentives. In our terminology, any economic decision, on the other hand, is the outcome of two motivational drivers: "purposive" and "cognitive" (Lowe, 1976). The purposive strand refers to the objective function of the agent and the cognitive strand denoted as expectations refers to the context in which the prospective action is to take place. People construct patterns out of disparate pieces of data. Knowledge is inchoate and only comes to the fore in the market process. A worker is an innovator in her job. Her personal unrepeatable accumulation of capital vanishes when she quits. Imagination, independent of external stimuli, is always at work. Furthermore, shared imagination is the basis of economic evolution (Harashima, 2011; Dopfer, 2011; Kirman, 2011).

In particular, expectations concern the present state of the market as well as any time points producers and consumers consider relevant for their decisions. In that case, a major impetus to "action directives" would be the extremum principle known as the profit motive. In our context, the quest for profits in microfinancial arrangements is part of the comprehensive critique of the model as it has evolved (Aitken, 2013). The original experiments held out the promise of decommodification, an economic logic outside the sway of the search for profits. However, through the set of practices connected with valuation, microcredit is subjected to the metrics associated with financial markets. Our constructive model is a response to the charge that modern microcredit is finance for its own sake, not oriented towards income generation.

Consider an initial equilibrium with less than full utilization of available resources. In each sector, there are technology entrepreneurs, characterized by their profit functions $\pi^{i}\left(p_{t}^{i}, p_{t+1}^{i} ; w\right), i=a, b, y$, that own blueprints for the 'full-employment' production of the specialized goods. However, they do not own wealth. Households, on the other hand, can bifurcate into workers and VCs. The VC receives in the second period a share of the profits in exchange for the technology transforming the inefficiently low level of output to the potential level. Properly, superscripts should distinguish VCs in the sectors as well. Ignoring them for the sake of brevity as all contracts are dependent on the same state vector, the stationary equilibrium of the system will be delivered by

$$
\pi^{i}\left(p^{i} ; w\right) \geq \pi^{i}\left(p_{t}^{i}, p_{t+1}^{i}, w\right), i=a, b, y
$$

with $p^{i} \equiv\left(p^{i}, p^{i}\right)$.

A structural equilibrium with footloose venture capital is likely to be inefficient as 'hit and miss' is the rule rather than the exception in the business. Much of venture capital is directed by hunches and herd behavior. A few spectacular success stories mask the low return rate of the others in the industry. Accordingly, institutionalists have proposed that the criterion of success in venture capital funding of entrepreneurial decisions be a social subject (Gimmon and Levie, 2010). Instrumental value theory has been proposed to that end. We have adopted 
the approach of Lowe but all variants offer the sequence ends-means for the purpose of appraisal. Nelson et al. (2004) have theorized the implant of innovations like new farming methods which are intended to play an instrumental role in activities where there is a consensus, at least at the abstract level, about objectives. In other words, there exist generallyaccepted criteria of value by which an innovation is appraised which focus and constrain the debate about its importance. It is critical then for an economy to channel capital to where it is need on the basis of financial institutions equipped with appropriate incentives (Stiglitz, 2004). These mechanisms would naturally be expected to fund small enterprises and deliver microcredit facilities. In keeping with the constructivist implications of force analysis we conjecture that the goal of the economy will be met by only by installing VCs in Sector II.

Proposition. Only contracts written in Sector II are subgame perfect.

Proof. We proceed in two steps. The first is positive. We assume that the participation constraints of the VCs are met. That is, their profit shares are not less than the wage income they would receive as workers. In that case, the working of the profit motive across the economy will be as follows. The last of the three price conditions above is now an equality. However, by virtue of the first of the two conditions of intertemporal equilibrium, full utilization of Sector Ib output is the outcome. Working upwards and backwards, the second of the price inequalities is now an equality. One implication for the right-hand side is that $p_{t}^{a}=p_{t+1}^{a}=p^{a}$. The second condition for intertemporal equilibrium ensures that the variables on the left-hand side of the first equation of Sector la are at their stationary equilibrium levels. In that case, equipment goods Sector la operates at the full employment level as well.

The second step is proof by contradiction. What if VC-entrepreneur contracts are written in Sector $\mathrm{Ib}$ ? In the present period, $t$, the entrepreneur would pledge an incentivecompatible and individually-rational share of profits to the VC in period $t+1$. However, this promise need not be credible because neither party can commit to a value of the exogenous state variable $p_{t+1}^{b}$. Finally, consider a financial-innovation push in Sector la. The first equality in our value space ensures the stationary equilibrium price $p_{t}^{a}=p_{t+1}^{a}=p^{a}$. By the second condition of stationary equilibrium, the result is an equality in the second equation of our price system as well. However, by the identical consideration, the value of $p_{t+1}^{b}$ is an anticipated value and time-consistent contracts dependent on that variable cannot be written.

As indicated earlier, the economics of adverse selection and moral hazard might be less than illuminating as a discussion point. Indeed, the practice of group lending when members have fine-grained information about peers can be described as a situation of perfect information (Haldar and Stiglitz, 2016). Since the individuals are not related they are unlikely to be soft on cheating. Defaults brought about by acts of nature could be distinguished from strategic defaults. Contracts are informal. Social capital is more than implicit contracts. Cooperation in this case implies supporting fellows in their productive processes increasing, by that means, own abilities to pay. Informal law requires that defaults be seen but not necessarily publicly verifiable. For Post Keynesians, the formation of a perspective on the economics of information would benefit from the ruminations of the stalwart founding fathers 
of the Cowles Commission (Mirowski and Nik-Khah, 2016). They started out working with information as a fungible commodity and moved to treating it as a topic in statistical induction. We offer the following general proposition: the economics of asymmetric information that bedevils principal and agent is part of "force analysis". We cannot move from "force analysis" to "structural analysis". The latter determines the former. What applies to "structural analysis" is perfect state information. Nobody can be unaware of stocks piling up in warehouses or workers at the factory gates. At most from a policy angle the data might be contaminated, making it imperfect. The monetary and fiscal authorities must extract signals from the noise. Indeed, a corollary of the result is explicit contracts that might be entered into by government and the private sector in Sector I. The well-known ground on which these arrangements must be writ is the incalculable uncertainties associated with large-scale capital investments that Keynes devoted much attention to. The government can underwrite a nation-wide irrigation project, for instance, through the instrumentality of a consortium of nationalized banks. An economics of the "public non-market" can be written (Sekera, 2015). Thus, government is a collective representation of the people. Production is the creation of utilities. The triggers, though, are neither demand nor profits but needs. At the same time, "collective payments" are made to the producer. The supply conditions are unique and non-rival as are the products/services. Notional buyers are absent and there is expenditure without spending. Finally, a concept of efficiency runs through the sub model but it is not market efficiency.

A structural appraisal for a developing country can be provided along lines etched by Kalecki (Toporowski, 2006). It is for governments to decide on the sectors in which finance must flow. Only the State can work out a model of dynamic growth as against a regime of inflation and luxury consumption. Capital from abroad is welcome in order to relax the domestic constraint and, indeed, can support government programmes by means of contracts written with suppliers of education and health equipment and so on. Care must be exercised because foreign capital is not always available in mutually beneficial forms. Viewing the matter through the lenses of the agents, both small and large farmers prefer government intervention and credit facilities which are sensitive to local conditions (Carney, 2010). They are less attracted to large banking networks and capital markets. Labor, as well, prefers government intervention through the medium of finance. The latter is critical during downturns in economic activity with the threat of layoffs. Finally, from an evolutionary perspective, the coevolution of venture capital and microfinance must run alongside an adaptive view of policy making (Rosiello et al., 2011). Governments must be alive to systems failure. For the purpose, along with the supply conditions that drive venture capital, they must create the demand curve in the form of a thick set of investor-friendly projects.

\section{Connections with contemporary Post Keynesian themes}

A positive appraisal of the current conjuncture is that the connection between profits and investment has snapped (Onaran, 2016). The well-known reason is the allure of finance. Despite booking a smart level of profits, private investment continues to remain lackluster in the advanced economies particularly as firms direct their profits to the financial circuit. Research on the investment behavior of non-financial companies in the US, the UK, and the EU15 has established a crowding out effect: financial portfolios crowd out private investment in machinery and equipment. The failure of effective demand is only underlined. Investment 
continues to be pivotal for long-run growth. The assumption of diminishing returns to capital across countries seems unfounded (Nell and Thirlwall, 2017). Echoing Kaldor, the productivity of investment is positive and high both in developed and developing countries.

We continue in our familiar way by subdividing this theme into ends and means. With regard to the first, our policy destination might have a welcome connection with the modern Post Keynesian deflection from manufacturing as the hub of job creation to servicebased industry (Tcherneva, 2017). The employment content of manufacturing has dropped dramatically. Jobs in that sector have fallen because of technological obsolescence but also because manufacturing cannot be effective-demand driven anymore. As with agricultural commodities first, satiation points have been reached with regard to manufactured goods across the world. What about possible technical change? The direct impact of process innovation would be retrenchments as the same quantity of output could be produced with less labor input. Marx recorded a "compensation theory", on the other hand, according to which new jobs would be created in the capital-goods producing sector as fresh machines were constructed (Piva and Vivarelli, 2017). Since labor-saving innovations would reduce the unit costs of production, prices would fall creating new demand for products and thereby additional employment. Compensation could occur within the labor market itself as reduced wages turned the clock back toward labor-intensive techniques. The Post Keynesian critique is that a fall in aggregate demand is not compensated for by a fall in prices. Behind the latter is the assumption of perfect competition: a fall in marginal costs equals a fall in prices. When animal spirits have evaporated, accumulated profits do not translate into fresh investment. Coming to product innovations, job-creation seems tacit in the rolling out of new products and product differentiation of existing products. However, this 'welfare effect' must be counterpoised against the 'substitution effect' in the displacement of mature products.

In the US surely, most of the regular employment is directed towards the reproduction of the labour force, in education, care, health, entertainment. The task then is to expand programs that are geared towards basic living expenses like retirement and healthcare. The traditional financial means to affect output and investment would be banks. Post Keynesians have always regarded the interest rate as a weak plank to walk on. At best, there are regular nods towards 'low' interest rates. However, enduring low rates reduce the profitability of banks as margins get squeezed. In what has been termed a "retail deposits endowment effect", bank deposit rates are a markdown on market rates reflecting imperfect competition and transactions costs (Borio and Gambacorta, 2017). If money market rates move downwards and margins consequently dwindle, net income will fall. The relationship between net interest income and interest rates is concave. Under the circumstances, avenues like the underwriting of the issuance of securities or mergers and acquisitions, insurance, turn out to be more profitable. These wholesale business activities are unlikely to depend upon cheap retail deposits. Thus, banks would prefer market share rather than profits as a performance metric, holding to a minimum profits constraint so as to appease shareholders. In that case, a fall in profits means a cutback in volumes so as to meet minimum targets.

\section{Conclusion}

Our discussion is reminiscent of the profound debates of the previous century concerning the relative merits of capital-goods-led growth and consumer-goods-led growth. 
The monetary and financial subsectors of that generation of models were rudimentary and undeveloped. The present exercise is an attempt to include some standard intertemporal considerations in incorporating financial contracts in a growth model. At the same time, modern discussions of venture capital and the like are rarely embodied in structural frameworks. The paper can be regarded as a contribution to that literature. In sum, the case is made for the encouragement and patronage of venture capital from home or abroad in the production and financing of basics. In classical-Marxian language, basics are commodities consumed by the working class in contrast to non-basics or luxuries consumed by the capitalist class. We need to acknowledge the mammoth task in front of governments in the event of a successful attack on non-basics production and the flowering of basics activity. Workers from the former will have to be absorbed in the latter.

The distinction is blurred under the current dispensation of financialisation. The link between finance capital and commodity production is snapped. One consequence of the return domination of financial instruments is that activity in the two or three classical-Marxian Departments shrink. The principle of arbitrage ensures that workers find it more attractive to turn rentiers. The familiar instruments of monetary and fiscal policy, both price and quantity, have been stretched to their limits and have served only to strengthen financial interests with no impact on employment and output. Post Keynesians and others have worked out the details of directed employment generating schemes in country after country. The financial implications have not been spelt out. Indeed, environmentally-friendly or green projects are likely to be costly upfront. We have made the case for the encouragement of non-standard directed credit to labor-using innovations in schools and hospitals and the care industry. Microcredit moved to microfinance under the impetus of optimizing consumption (savings) streams over time. Beginning with an initial condition of being unbanked, the principle is to generate income and thus savings. With a deposit in a bank the macroeconomic circuit originating in a debt to a borrower is closed. Otherwise put, starting out with a condition of no collateral financial collateral is slowly built up. The case for VC intervention is to provide point and purpose and horizon so that life-cycle planning can be autonomous as soon as possible.

Displaying the positive present value of the multi period connection between costs and liabilities of other such financial-real models is the task for future research.

\section{References}

Aitken, R. (2013) "The Financialization of Micro-Credit", Development and Change 44 (3), p. 473-499.

Aghion, B. and Morduch, J. (2005) The Economics of Microfinance. Cambridge, Massachusetts: The MIT Press.

Allen, F. and Oura, H. (2004) "Sustained Economic Growth and the Financial System", Monetary and Financial Studies, 22 (S-1), p. 95-118.

Ashford, R. (2013-14) "Beyond austerity and stimulus: democratizing capital acquisition with the earnings of capital as a means to sustainable growth", Journal of Post Keynesian Economics, 36 (2), p. 179-205. 
Beckert, J. (2011) "Where do prices come from? Sociological Approaches to Price Formation", Max Planck Institute for the Study of Societies Discussion Paper 11/3

Borio, C. and Gambacorta, L. (2017) "Monetary Policy and bank lending in a low interest environment: diminishing effectiveness", BIS Working Paper No. 612

Carney, R. (2010) Contested Capitalism. Oxford: Routledge.

Cumming, D., Fleming, G. and Suchard, J-A. (2005) "Venture capitalist value-added activities, fundraising and drawdowns", Journal of Banking \& Finance, 29 (2), p. 295-331.

Donaghue, K. (2004) “Microfinance in the Asia Pacific", Asia-Pacific Economic Literature, 18 (1), p. 41-61.

Dopfer, K. (2011) "Evolution and Complexity in Economics revisited", Max Planck Institute of Economics, Papers on Economics and Evolution No. 1102

Downward, P. (2004) "Post Keynesian pricing theory: Alternative foundations and prospects for future research", Journal of Economic Psychology, 25 (5), p. 661-670.

Engelen, E., Erturk, I., Froud, J., Leaver, A. and Williams, K. (2010) "Reconceptualizing financial innovation: frame, conjuncture and bricolage", Economy and Society, 39 (1), p. 33-63.

Evangelista, R. (2015) "Technology, development and economic crisis: the Schumpeterian legacy", Birbeck College, University of London, CIMR (Centre for Innovation Management Research) Working Paper No. 23

Fernández, R.G. and Suprinyak, C.E. (2016) "Manufacturing Pluralism in Brazilian Economics: The role of ANPEC as institutional mediator and stabilizer", Cedeplar Texto Para Discussão, No. 545

Gimmon, E. and Levie, J. (2009) "Instrumental Value Theory and the Human Capital of Entrepreneurs", Journal of Economic Issues, 43 (3), p. 715-732.

Gimmon, E. and Levie, J. (2010) "Authors' response to Comments by Baldwin Ranson on "Instrumental Value Theory and the Human Capital of Entrepreneurs", Journal of Economic Issues, 44 (1), p. 268-270.

Goodwin, N. (2014) "Prices and Work in the New Economy", Global Development and Environmental Institute Working Paper No. 14-01

Haldar, A and Stiglitz, J.E. (2016) "Group Lending, Joint Liability, and Social Capital: Insights from the Indian Microfinance Crisis", Politics and Society, 44 (4), p. 459-497.

Harashima, T. (2011) “A Model of TFP Built on Hayek's View of Knowledge: What Really Went Wrong with Socialist Mixed Economies?" MPRA Paper No. 29107, February 26, 2011

Hollis, A. and Sweetman, A. (2004) "Microfinance and Famine: The Irish Loan Funds during the Great Famine", World Development, 32 (9), p. 1509-1523.

Keuschnigg, C. (2004) "Venture Capital Backed Growth", Journal of Economic Growth, 9 (2), p. 239-261.

Kirman, A. (2011) Complex Economics, New York: Routledge.

Klinger-Vidra, R. (2016) "When Venture Capital is patient capital: seed funding as a source of patient capital", Socio-Economic Review, 14 (4), p. 691-708. 
Langlois, R.N. (2013) "The Institutional Revolution: A Review Essay", University of Connecticut Department of Economics Working Paper No. 2013-11

Lecouteux, G. (2013) "Reconciling Behavioural and Neoclassical Economics", Cahier n ${ }^{0} 2013-$ 09, Ecole Polytechnique Centre National De La Recherche Scientifique

Lee, F. (2011) "Heterodox microeconomics and the foundation of heterodox macroeconomics", MPRA Paper No. 30491, April 25

Lee, F. and Tae-Hee, J. (2010) "Social Surplus approach and heterodox economics", Munich Personal RePec Archive Paper No. 27636

Lin, J.Y. (2013) "New Structural Economics: the third wave of development thinking", AsiaPacific Economic Literature, 27 (2), p. 1-13.

Lowe, A. (1976) The Path of Economic Growth, Cambridge: Cambridge University Press.

MacKenzie, D. and Pardo-Guerra, J.P. (2014) "Insurgent Capitalism: Island, bricolage and the re-making of finance", Economy and Society, 43 (2), p. 153-182.

Mayer, C. (2004) "The financing and governance of new technologies", in Fan, J., Hanazaki, M. and Teranishi, J. (Eds.), Designing Financial Systems in East Asia and Japan, New York: Routledge, p. 187-203.

Menudo, J.M. (2011) "Market Stability in Adam Smith: Competitive Process and Institutions", MPRA Paper No. 15361, July 2011

Mirowski, P. and Nik-Khah, E. (2016) "The Role of the Cowles Commission in the History of Information Economics", Methodological Studies, 36, p. 59-85.

Nell, K.S. and Thirlwall, A. P. (2017) "Why does productivity of investment vary across countries?", University of Kent School of Economics Discussion Paper No. 1703

Nelson, R.R., Peterhead, A. and Sampat, B. (2004) "Why and how innovations get adopted: a tale of four models", Industrial and Corporate Change, 13 (5), p. 679-699.

Penender, M. and Resch, A. (2014) "Schumpeter and Venture Finance", WIFO Working Paper No. $490 / 2014$

Piva, M. and Vivarelli, M. (2017) "Technological Change and Employment: Were Ricardo and Marx Right?", IZA Institute of Labor Economics Discussion Paper No. 10471

Popov, A. and Roosenboom, P. (2013) "Venture capital and new business creation", Journal of Banking and Finance, 37 (12), p. 4695-4710.

Rosiello, A., Avnimelech, G. and Teubal, M. (2011) "Towards a systemic and evolutionary framework for a venture capital policy", Journal of Evolutionary Economics, 21 (1), p. 167-189.

Sachs, I. (2004) "Inclusive development and decent work for all", International Labor Review, 143 (1-2), p. 161-184. 
Sawyer, M. (2013) "Bank-based versus market-based financial systems: a critique of the dichotomy", FESSUD (Financialisation, Economy, Society and Sustainable Development) Working Paper No. 19

Schäfer, D.,Wermatz, A. and Zimmerman, V. (2004) "The Determinants of Debt and (Private) Equity Financing: The Case of Young, Innovative SMEs from Germany", Industry and Innovation, 11 (3), p. 225-248.

Schlicht, E. (2014) "Two Additional Remarks on Conformism", University of Munich Department of Economics Discussion Paper No. 2014

Sekera, J. (2015) "Economics and the Near-Death Experience of Democratic Governance", Global Development and Environment Institute Working Paper No. 15-02

Seppecher, P., Salle, I.L. and Lavoie, M. (2017) "What drives markups? Evolutionary pricing in an agent-based stock-flow consistent macroeconomic model", CEPN (Centre d'economie de l'Université Paris Nord) Working Paper, No. 2017-03

Stiglitz, J. (2004) "Finance for development", in Ayigu, M. and Ross, D. (Eds.), Development Dilemmas, New York: Routledge, p. 15-29.

Tcherneva, P. R. (2017) “Trump's bait and switch: job creation in the midst of welfare state sabotage", real-world economics review, 78 (1), p. 148-178.

Temin, P. (2004) "Financial Intermediation in the Early Roman Empire", The Journal of Economic History, 64 (3), p. 705-733.

Toporowski, J. (2006) "Michal Kalecki", in Clark, D.A. (Ed.), The Elgar Companion to Development Studies, Cheltenham: Edward Elgar, p. 304-308.

Wagner, C. and Winkler, A. (2013), "The Vulnerability of Microfinance to Financial Turmoil Evidence from the Global Financial Crisis", World Development, 51, p. 71-90. 